\title{
The expression of cytochrome P4502J2 gene and 14, 15 epoxyeicosatrienoic acid level influence the amount of insulin secreted from human mesenchymal stem cell-derived insulin-producing cells
}

\author{
Loaa A. Tag Eldeen*, Marow El Sheikh and Salwa Faisal
}

\begin{abstract}
Background: Insulin-producing cells differentiated from human mesenchymal stem cells demonstrate limited glucose-stimulated insulin secretion. Cytochrome P450 2J2 and its product epoxyeicosatrienoic acids regulate $\beta$-cell function in the human pancreas. The aim of this study is to explore the expression pattern of cytochrome P450 $2 J 2$ gene and 14, 15 epoxyeicosatrienoic level along the differentiation of human bone marrow-derived mesenchymal stem cells into insulin-producing cells.

Results: The differentiated insulin-producing cells express high levels of pancreatic duodenal homeobox-1 and insulin gene mRNA. It secretes increasing amounts of C-peptide in response to increasing glucose concentrations than undifferentiated cells. The differentiated insulin-producing cells were found to express reduced amounts of cytochrome P450 2J2 gene mRNA and significant low level of 14, 15 epoxyeicosatrienoic acid than the undifferentiated cells. A strong positive correlation between 14, 15 epoxyeicosatrienoic concentrations and C-peptide released from the differentiated insulin-producing cells was noticed.
\end{abstract}

Conclusions: Cytochrome P4502J2 and its product 14, 15 epoxyeicosatrienoic might affect insulin secretion from differentiated insulin-producing cells.

Keywords: Insulin-producing cells, Cytochrome P4502J2, 14, 15 Epoxyeicosatrienoic acid, Pancreatic duodenal homeobox-1 mRNA, Insulin mRNA, Human mesenchymal stem cells

\section{Background}

Mesenchymal stem cells (MSCs), self-renewable multipotent stromal cells, are usually isolated with relative ease from several organs, including the liver, umbilical cord, and bone marrow (Vanella et al. 2010). Under certain culture conditions, bone marrow-derived MSCs (BM-MSCs) can be differentiated into insulin-producing cells (IPCs). It is characterized by expressing both the pancreatic $\beta$-cell developmental genes as pancreatic duodenal homeobox-1 (PDX-1) gene, and functional genes as insulin and glucagon genes (Zanini et al. 2011; Xie et

\footnotetext{
* Correspondence: loaa_tag@hotmail.com

Medical Biochemistry and Molecular Biology Department, Suez Canal Faculty of Medicine, Ismailia 411522, Egypt
}

\section{Springer Open}

(c) The Author(s). 2018 Open Access This article is distributed under the terms of the Creative Commons Attribution 4.0 International License (http://creativecommons.org/licenses/by/4.0/), which permits unrestricted use, distribution, and reproduction in any medium, provided you give appropriate credit to the original author(s) and the source, provide a link to the Creative Commons license, and indicate if changes were made. but also reverses hyperglycemia in drug-induced diabetic mice (Sun et al. 2007; Chen et al. 2004). Therefore, induction of IPCs offers an approach to supply donor $\beta$-cell sources for diabetes cell therapy and screen new anti-diabetic drugs (Xie et al. 2009; Sun et al. 2007; Volarevic et al. 2010).

However, the generation of IPCs from MSCs occurs at a low rate, and most of these induced cells show limited glucose-stimulated insulin secretion (GSIS), which limits basic and clinical applications (Xie et al. 2013). Consequently, understanding metabolic pathways related to 
IPC induction and insulin secretion has become an essential and vital issues.

Cytochrome P4502J2 (CYP2J2), an arachidonic acid epoxygenase, is widely expressed in various human tissues, such as the heart, lung, blood vessels, liver, kidney, ileuma, and jejunum, and highly expressed in pancreatic Langerhans cells (Xu et al. 2013; Zeldin et al. 1997).

CYP2J2-derived epoxyeicosatrienoic acids (EETs), a set of lipid intermediaries, have diverse biological and cytoprotective properties (Sodhi et al. 2009). EETs promote endothelial cell growth and angiogenesis and inhibit apoptosis (Wang et al. 2005). As well, EETs posse an anti-inflammatory effect via the suppression of NF- $\mathrm{KB}$ and IкB kinase activity (Node et al. 1999).

Moreover, a significant amount of EETs is produced in the human and rat pancreas, providing biochemical evidence that CYP epoxygenase product may regulate $\beta$-cell function (Zeldin et al. 1997). Upon production, 90\% of EETs esterifies at the $s n-2$ position of glycerophospholipids where they are stored and released according to the cell's needs (Karara et al. 1991). Free EETs are unstable, either transformed by soluble epoxide hydrolase $(\mathrm{sEH})$ to the less active dihydroxyepoxytrienoic acids or undergo $\beta$ oxidation (Abraham et al. 2014).

Earlier reports stated that human MSCs not only exhibit a considerable amount of CYP2J2 and synthesized significant levels of EETs (Kim et al. 2010), but their levels also modulate adipogenesis and cell differentiation in MSC-derived adipocytes (Vanella et al. 2011).

The expression of CYP2J2 gene in differentiated IPCs is not yet investigated. Therefore, we aim in this study to investigate the expression pattern of CYP2J2 gene and 14, 15 EET level along the differentiation of human bone marrow-derived MSCs into IPCs.

\section{Methods}

\section{Isolation and culture of human bone marrow-derived} MSC (HBM-MSCs)

Bone marrow aspirates (BMA) were obtained from the iliac crest of three non-diabetic adult volunteers (age 35-65 years), during hip replacement surgery under approved protocol by the faculty of medicine ethical committee, Suez Canal University. Written informed consent was obtained from the volunteers. The HBM-MSCs were isolated and cultured as previously described (Gabr et al. 2013).

In brief, mononuclear cells were isolated from BMAs diluted with low glucose DMEM (Dulbecco's modified Eagle's medium) by density gradient centrifugation in Ficoll-Paque $1.077 \mathrm{~g} / \mathrm{mL}$ (Lonza BioWhittaker, Belgium). The cells, $\left(5 \times 10^{6}\right) / \mathrm{BMA}$, were cultured in a complete growth medium (low glucose (1 g/L) DMEM,10\% heat-inactivated fetal bovine serum (FBS), 1\% penicillin, 1\% streptomycin [Lonza BioWhittaker, Belgium], and 1\% L-glutamine (Gibco BRL, Life Technologies, UK). After
$72 \mathrm{~h}$, the non-adherent cells were discarded. When the adherent cells reached $80 \%$ confluence, it is trypsinized and expanded by re-plated for two passages (P1-P2), 8 days each.

\section{Differentiation of HBM-MSCs into IPC}

At P3, the homogenous, spindle-shaped, fibroblast-like MSCs were induced to differentiate into IPCs by a three-stage protocol described (Gabr et al. 2013). In short, MSCs were cultured in serum-free, glucose-rich $(25 \mathrm{mmol} / \mathrm{L})$ DMEM containing, firstly, $0.5 \mathrm{mmol} / \mathrm{L}$ $\beta$-mercaptoethanol (Sigma) for 2 days; secondly, $2 \mathrm{mmol} / \mathrm{L}$ L-glutamine, 2\% B27 supplement (Gibco BRL, Life Technologies, UK), $1 \%$ non-essential amino acids, $20 \mathrm{ng} / \mathrm{mL}$ epidermal growth factor, and $20 \mathrm{ng} / \mathrm{mL}$ basic fibroblast growth factor (Sigma) for 8 days; and finally, $10 \mathrm{ng} / \mathrm{mL}$ activin-A, $10 \mathrm{ng} / \mathrm{mL}$ betacellulin, $10 \mathrm{mmol} / \mathrm{L}$ nicotinamide (Sigma), and 2\% B27 supplement for another 8 days. The medium was replaced at the third day in every stage. At the end of the differentiation protocol (18 days), the cells become spherical and tend to form islet-like clusters.

\section{Flow cytometry characterization of MSC cell markers}

At P3, the cells were incubated with the following antibodies against CD105 (FITC), a positive marker of MSC and CD45 (PerCP), CD34 (PE) a negative markers of MSC (BioLegend, USA) as previously described (Gabr et al. 2013).

\section{Evaluation of insulin, PDX-1, and CYP2J2 gene expression by real-time PCR}

Total RNA was extracted from undifferentiated MSCs (control) at P3 and differentiating cells at days 18 by QIAamp RNA Blood Mini Kit (Valencia, CA, USA ca. no. 52304). Total RNA was converted to cDNA using QuantiTect Reverse Transcription Kit (Catalog no. 205311).

Quantitative real-time PCR amplification was done using QuantiTect SYBR Green PCR Kit (Catalog no. 204141, QIAGEN Inc., Valencia, CA, USA), and a step one Real-Time PCR System (ABI PRISM, Applied Biosystem, CA, USA). Relative gene expression was assessed using comparative cycle threshold (CT) to determine the fold change $\left(2^{-\Delta \Delta \mathrm{Ct}}\right)$ of gene expression between samples and normalized to an endogenous reference (GAPDH $H^{1}$ for insulin and PDX-1, GAPDH $H^{2}$ for CYP2J2) (Livak and Schmittgen 2001).

\section{$P C R$ reaction mix}

One to $2 \mu \mathrm{l}$ of the cDNA was amplified in $20 \mu \mathrm{L}$ total volume including $10 \mu \mathrm{l}$ of $2 \mathrm{x}$ Quantitec SYBR green PCR master Mix (QIAGEN, Valencia, CA), nuclease-free water, and $25 \mathrm{pmol}$ of each of the following primer pair (Table 1). 
Table 1 Primers used in this study

\begin{tabular}{ll}
\hline Gene & Primers \\
\hline Insulin & F: 5'CTACCTAGTGTGCGGGGAAC3', \\
& R: 5' CACAATGCCACGCTTCTG3' \\
PDX-1 & F: 5'GAGCTGGCTGTCATGTTGAA3', \\
& R: 5'AGTGGTTGAAGCCCTCAG3' \\
GAPDH & F: 5'TGCTGGCGCTGAGTACGTCG3', \\
& R: 5'TGACCTTGGCAGGGGTGCT3' \\
CYP2J2 & F: 5'CTCCTACTGGGCACTGTCGC3', \\
& R: 5'TGGGCCTCCTCCTGAAT3' \\
GAPDH ${ }^{2}$ & F: 5'CCAGGTGGTCTCCTCTGACTTC3', \\
& R: 5'TCATACCAGGAAATGAGCTTGACA3' \\
\hline
\end{tabular}

\section{PCR cycling conditions}

Insulin: Initial heat activation $95{ }^{\circ} \mathrm{C}, 15 \mathrm{~s} ; 30$ cycles of denaturation $94{ }^{\circ} \mathrm{C}, 30 \mathrm{~s}$; annealing $61{ }^{\circ} \mathrm{C}, 30 \mathrm{~s}$; extension $72{ }^{\circ} \mathrm{C}, 30 \mathrm{~s}$.

$P D X-1$ : Initial heat activation $95{ }^{\circ} \mathrm{C}, 15 \mathrm{~s} ; 30$ cycles of denaturation $94{ }^{\circ} \mathrm{C}, 30 \mathrm{~s}$; annealing $57{ }^{\circ} \mathrm{C}, 30 \mathrm{~s}$; extension $72{ }^{\circ} \mathrm{C}, 30 \mathrm{~s}$.

CYP2J2: Initial heat activation $95{ }^{\circ} \mathrm{C}, 15 \mathrm{~s} ; 45$ cycles of denaturation $95{ }^{\circ} \mathrm{C}, 15 \mathrm{~s}$; annealing $56{ }^{\circ} \mathrm{C}, 30 \mathrm{~s}$; extension $72{ }^{\circ} \mathrm{C}, 40 \mathrm{~s}$.

Reactions were performed on a step one Real-Time PCR System (ABI PRISM, Applied Biosystem, CA, USA).

Determination of insulin secretion by differentiated MSCs Insulin secretion was determined indirectly by evaluating $\mathrm{C}$-peptide release in culture media in response to increasing glucose concentrations. Cells at the end of differentiation were initially incubated for $3 \mathrm{~h}$ in glucose-free Krebs-Ringer bicarbonate buffer (KRB) followed by incubation in $3.0 \mathrm{~mL}$ of $\mathrm{KRB}$ containing 5.5 , 12, or $25 \mathrm{mM} / \mathrm{L}$ glucose for $1 \mathrm{~h}$. Supernatant C-peptide concentrations were assayed using Human C-Peptide ELISA Kit (Biovendor, cat no. RIS005R) according to the manufacturer's instructions.

\section{Determination of 14, 15-DHET level}

To investigate the function of CYP2J2, the concentration of 14, 15-dihydroxyeicosatrienoic acid (14, 15-DHET), the stable EET metabolite, was measured. Cell culture media of differentiated and undifferentiated MSCs were centrifuged at $1500 \mathrm{rpm}$ for $10 \mathrm{~min}$ at $4{ }^{\circ} \mathrm{C}$. Cell supernatant was collected, and 14, 15-DHET concentration was determined by 14, 15 EET/DHET ELISA Kit (AB175812, ABCAM, USA), according to the manufacturer's instructions.

\section{Determination of 14, 15-DHET level in insulin-producing cells}

To evaluate the relation between 14, 15-DHET level and C-peptide release, both 14, 15-DHET and C-peptide levels were measured in the cell supernatant of differentiated MSCs obtained from the three donors and incubated in $3.0 \mathrm{~mL}$ of KRB containing $25 \mathrm{mM} / \mathrm{L}$ glucose for $1 \mathrm{~h}$ by 14, 15 EET/DHET ELISA Kit (AB175812, ABCAM, USA), and Human C-Peptide ELISA Kit (Biovendor, cat no. RIS005R) according to the manufacturer's instructions.

\section{Data analysis}

Statistical analysis was performed using SPSS V22.0 and Microsoft Excel 2007. Non-parametric data were evaluated by Kruskal-Wallis test. A $P$ value of $<0.05$ was considered significant.

\section{Results \\ Morphological characterization of cultured cells}

Adherent cells were detected $24 \mathrm{~h}$ after culture. The appearance of spindle-shaped MSC-like adherent cells was noticed 3-7 days $(3.7 \pm 1.6)$ after onset of culture. With time, the colonies of spindle-shaped adherent MSC-like cells survive and predominate (Fig. 1).

\section{Phonotypical characterization of cultured cells at the end of expansion stag}

The surface antigens on the P3 HBM spindle-shaped MSC-like cells were analyzed by flow cytometry. It showed them expressing statistically significant high levels of CD105 compared to CD34 and CD45 $(P<0.05)$ (Fig. 1).

\section{Validation of IPCs derived from HBM-MSCs}

P3 HBM-MSCs were induced to differentiate into IPCs by a three-step, 18-day protocol. At day 6 of differentiation, the cells become shorter and began to collect, forming cellular aggregates. With contentious culture, spheroid epithelial-like cells tend to aggregate into islet-like cluster (Fig. 2).

$m R N A$ expression of pancreatic development transcription factor, $P D X 1$, and endocrine-related marker gene, insulin, were analyzed by quantitative real-time PCR. The gene transcripts of the differentiated cells are compared with that of undifferentiated hMSCs (control). The expression of $P D X-1$ and insulin genes in the differentiated cells was significantly higher than undifferentiated cells $(P<0.05)$ (Table 2$)$.

At the end of the differentiation protocol, the differentiated cells were found to secrete increasing amounts of $\mathrm{C}$-peptide in response to increasing glucose concentrations $(P<0.05)$. C-peptide is released when pro-insulin is cleaved to insulin, and as such, it has been considered as a marker for insulin secretion (Table 3). 


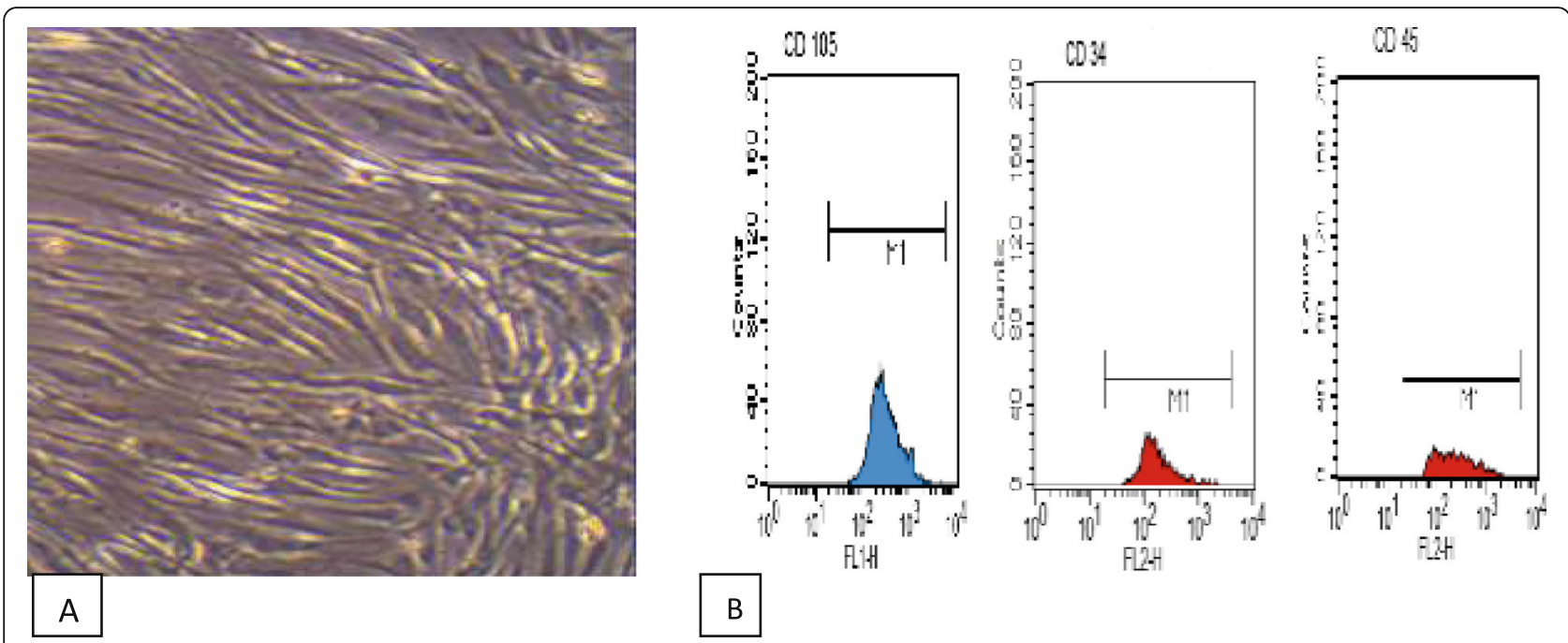

Fig. 1 a Undifferentiated spindle-shaped HBM-derived MSCs at the end of expansion phase ( $80 \%$ confluence, $\times 100)$. b Surface expression of the CD105, CD34, CD45, on HBM-MSC cells at P3. CD105 (endoglin and SH2) was expressed in $60.3 \pm 3.6$ of cells, while CD34 (hematopoietic stem cell marker) and CD45 (common lymphocytes antigen) were shown to be expressed in $25.1 \pm 3.9$ and $19.1 \pm 1.6$ of cells respectively $\left(P=0.001^{*}\right)$

\section{CYP2J2 gene expression and 14, 15-DHET level before and after differentiation}

The differentiated IPCs express non-significant reduced amounts of CYP2J2 gene mRNA than the undifferentiated HBM-MSCs cells $(P=0.31)$ (Table 2).

In addition, the 14, 15-DHET, which measured to represent levels of EETs production, was reduced significantly in the differentiated IPCs than the undifferentiated MSCs cells $(P<0.05)$ (Table 2).

\section{Relation between 14, 15 DHET concentration and C- peptide release}

Increasing 14, 15-DHET concentration was associated with increase in $\mathrm{C}$-peptide released from differentiated
IPCs incubated in KRB containing $25 \mathrm{mM} / \mathrm{L}$ glucose (Table 4).

Non-parametric Spearman correlation between 14, 15-DHET concentrations and C-peptide released from IPCs shows statistically significant strong positive correlation between them (rho $=1.000, P<0.01)$ (Fig. 3).

\section{Discussion}

Earlier studies reported an induction of limited functional insulin-producing cells, from bone marrow-derived MSCs of human origin, upon re-programming in vitro (Xin et al. 2016; Gabr et al. 2015; Jafarian et al. 2015).

In the current study, in an attempt to elucidate the reasons under this observation, we studied the expression of CYP2J2 gene and 14, 15 EET level, previously

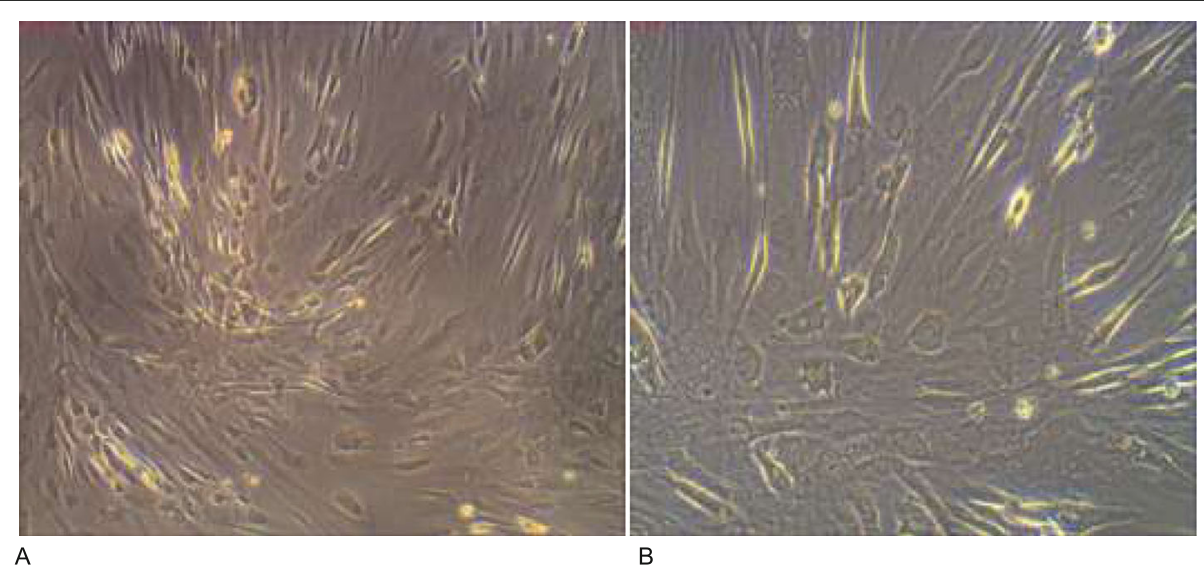

Fig. 2 Differentiation of hMSCs into insulin-producing cells (IPCs). HBM-MSCs at P3 were induced to differentiate into IPCs by an 18-day protocol. a After 14 days of induction, small round cell aggregates were formed. b At day 18 (the end of differentiation), more islet-like clusters and round epithelial-like cells appeared 
Table 2 Relative expression of PDX-1, insulin, CYP2J2 genes, and 14, 15-DHET conc. level before and after differentiation of HBMMSCs to IPCS

\begin{tabular}{llll}
\hline & $\begin{array}{l}\text { Undifferentiated } \\
\text { HBM-MSCs }\end{array}$ & $\begin{array}{l}\text { Differentiated } \\
\text { IPCs }\end{array}$ & $P$ value \\
\hline PDX-1 & $1.0 \pm 0.03$ & $5.5 \pm 0.9$ & $0.046^{*}$ \\
Insulin & $1.0 \pm 0.02$ & $3.0 \pm 0.2$ & $0.04^{*}$ \\
CYP2J2 & $1.0 \pm 0.37$ & $0.84 \pm 0.01$ & 0.31 \\
14-15DHET (pg/mL) & $4.85 \pm 0.6$ & $3.36 \pm 0.4$ & $0.005^{*}$ \\
\hline
\end{tabular}

*Statistically significant difference $(P$ value $<0.05)$

reported to be involved in the regulation of pancreatic $\beta$-cell function (Luo and Wang 2011), before and after differentiation of HBM-derived MSCs into IPCs.

For this purpose, HBM-derived plastic adherent cells, isolated from adult healthy donors, were selected (Friedenstein et al. 1976). These cells were expanded for two passages, after the original seed of bone mononuclear cells, to get more uniform hMSCs (Sun et al. 2007; Xin et al. 2016). At the end of the expansion stage, the majority of cells attain spindle-shaped morphology as well as are being positive for MSC marker CD105 (Dominici et al. 2006).

Yet, small populations of the cells were positive for either CD34 or CD45, a result contradicting other researchers (Gabr et al. 2013; Xin et al. 2016; Karnieli et al. 2007). However, considering CD34 and CD45 negative markers for MSCs is debatable. Several studies provided persuasive evidence that uncultured BM-MSCs are CD34+, and they tend to gradually lose CD34 expression during prolonged cell culture (Simmons and Torok-Storb 1991; Suga et al. 2007; Mouiseddine et al. 2008; Stolzing et al. 2012; Lin et al. 2012).

On the other hand, MSCs derived from different adult sources were found to express detectable level of CD45, ranging from 8 to $26 \%$ (15\%), in early passages, which decreases significantly with successive expansion (Gang et al. 2010; Maleki et al. 2014). Cell culture-associated loss of CD34 and CD45 expression may attribute to either downregulation of CD34/45 proteins or production of modified forms in cultured cells that are nonreactive with CD34/45 antibodies (Watt et al. 1987; Fina et al. 1990).

Other factors could contribute to the different MSC cell surface marker profiles. It may depend on MSC tissue source, medium composition, or passage number (Hass et al. 2011).

Table $\mathbf{3}$ In vitro C-peptide release in response to increasing glucose concentration

\begin{tabular}{lllll}
\hline & $\begin{array}{c}\text { Glucose } \\
5.5 \mathrm{mM}\end{array}$ & $\begin{array}{l}\text { Concentration } \\
12 \mathrm{mM}\end{array}$ & $25 \mathrm{mM}$ & $P$ value \\
\hline $\begin{array}{l}\text { Human C-peptide release } \\
\text { (ng/ } \mathrm{\mu g} \text { protein/hour) }\end{array}$ & $2.7 \pm 0.8$ & $3.8 \pm 0.8$ & $8.7 \pm 1.5$ & $0.04^{*}$ \\
(Mean \pm SD) & & & & \\
\hline
\end{tabular}

*Statistically significant difference $(P$ value $<0.05)$
Table 4 14, 15-DHET concentrations and C-peptide released from differentiated IPCs incubated in KRB containing $25 \mathrm{mM} / \mathrm{L}$ glucose

\begin{tabular}{llll}
\hline Donor & $\begin{array}{l}14,15-\mathrm{DHET} \\
(\mathrm{pg} / \mathrm{mL})\end{array}$ & $\begin{array}{l}\text { C-peptide } \\
(\mathrm{ng} / \mathrm{\mu g} \text { protein/hour })\end{array}$ & $P$ value \\
\hline $1^{*}$ & 3.8 & 10 & \\
$2^{*}$ & 3.28 & 9.1 & \\
$3^{*}$ & 3.1 & 7.1 & $* 0.000$ \\
\hline
\end{tabular}

*Statistically significant difference $(P$ value $<0.05)$

Since, in the current study, the cells were expanded for two passages (16 days), which is less than that reported in other studies, five passages ( 25 days) in Xin et al. (Xin et al. 2016), 2 p (28 days) in Jafarian et al. (Jafarian et al. 2015), and 28 days in Karnieli et al. (2007), which could explain the difference in MSC phenotypic picture. Although the expansion period in the current study was the same as in Gabr et al. (Gabr et al. 2013), the use of L-glutamine in the culture media of this study may contribute to the discrepancy between the results.

In this study, HBM-MSCs were induced to differentiate into IPCs using soluble factors, three-stage protocol that mimicked in vivo pancreatic $\beta$-cell formation and development (Gabr et al. 2013). The differentiation is confirmed by the fact that differentiated cells expressing insulin and $P D X-1$ genes, and secreting C-peptide in response to escalating glucose concentrations, results in concordance with other studies (Gabr et al. 2013; Xin et al. 2016).

In the current study, we assayed the $\mathrm{C}$-peptide release from the differentiated cells to ensure that the IPC cells were synthesizing insulin. Previous studied had argued that the release of insulin from such cells does not indicate intrinsic insulin production. They suggest that insulin could be absorbed from the utilized culture

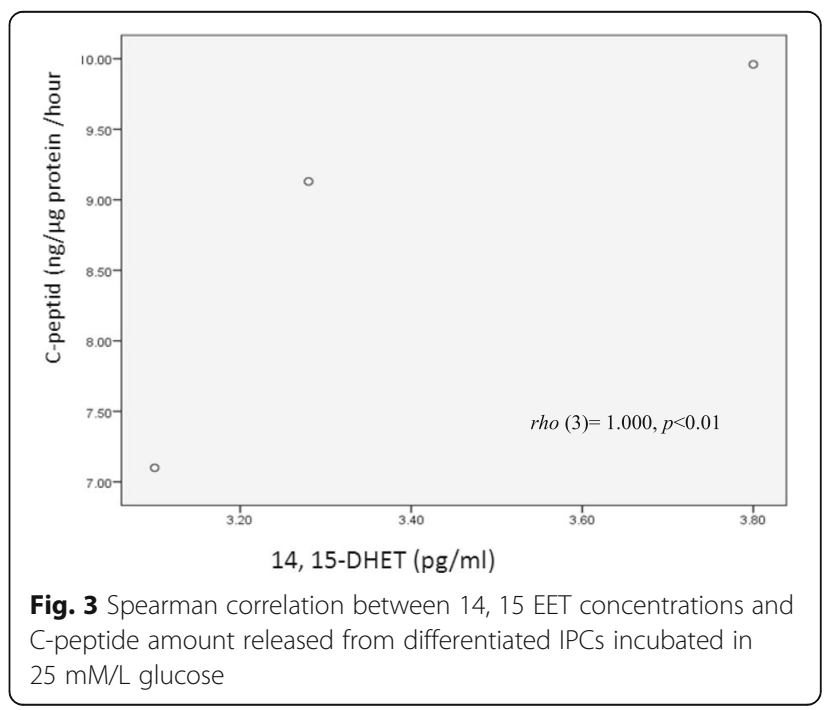


media (B27 containing additional insulin), sequestrated, and re-released upon glucose stimulation (Rajagopal et al. 2003; Hansson et al. 2004; Mc Kiernan et al. 2007).

However, the amount of C-peptide released from IPCs in the current study $(8.7 \mathrm{ng} / \mu \mathrm{g}$ protein /hour $/ 25 \mathrm{mM}$ glucose) is modest, representing $\approx 28 \%$ of equivalent quantity of C-peptide in pancreatic islet cells at $25 \mathrm{mM}$ glucose concentration (Gabr et al. 2013), a result comparable to that reported by Gabr et al. (Gabr et al. 2013).

Taking into consideration, the IPCs in the current study secrete C-peptide in a glucose-sensitive manner. It is proposed that the defect could be in the insulin release regulatory mechanisms, rather than the mechanism of cellular glucose sensing.

Glucose-stimulated insulin release is a complex process involving full oxidation of glucose by respiratory chain and production of ATP; rise in ATP/ADP ratio results in closer of the $\mathrm{K}_{\mathrm{ATP}}$-channels, results in depolarization of the plasma membrane followed by opening of the voltage-operated $\mathrm{Ca}^{2+}$ channels, and leads to influx of and increase of the intracellular $\mathrm{Ca}^{2}$ ${ }^{+}$, which direct insulin granule translocation, and eventually insulin exocytosis (Klett et al. 2013a).

Previous studies considered the role of CYP2J2 and its derivative EETs in the control of insulin secretion. Inhibition of cytochrome $\mathrm{P}_{450}$ decreased glucose-stimulated insulin release and arginine-stimulated insulin from isolated rat pancreatic islets (Zeldin et al. 1997; Falck et al. 1983; Chen et al. 2013). EETs, and their metabolites through activation of peroxisome proliferator-activated receptors (PPAR) $\gamma$, increase calcium mobilization and insulin secretion, which is mediated by the free fatty acid receptor, G-protein-coupled transmembrane 40 (GPR 40 ), and GLUT2 expression in pancreatic $\beta$-cells (Wray and Bailey 2007; Kim et al. 2013).

In addition, the glycophospholipd-EETs were reported to increase glucose-stimulated-insulin secretion more than free EETs (Klett et al. 2013b; Gangadhariah et al. 2017). Furthermore, decrease EET deprivation, by inhibiting $\mathrm{sEH}$ or deleting its encoding gene (Ephx2), results in increased insulin sensitivity and insulin secretion and increases islet survival (Luo et al. 2010).

In the current study, the HBM-MSC-derived IPCs display decreased activity of CYP2J2, as addressed by a decrease in CYP2J2 mRNA expression, and a significant decrease in 14, 15 EET level compared to the undifferentiated hMSCs. In addition, although of small sample size, a statistically significant strong positive correlation between 14, 15 EET concentration and C-peptide released from differentiated IPCs cells was found, as higher concentrations of 14, 15 EET are accompanied by increase in C-peptide released.

As a result, the low amount of insulin released from differentiated IPCs, in the current study, could be attributed to the relatively low 14, 15 EET level in the differentiated cells. 14,15 EET acts in an autocrine manner to affect the intracellular $\mathrm{Ca}^{2+}$ concentration via promoting $\mathrm{Ca}^{2+}$ influx through TRPV4, or TRPC3, and TRPC6 channels (transient receptor potential cation channel) (Campbell and Fleming 2010). In addition, evidence exists that 14, 15 EET markedly alter the activity of $\mathrm{K}_{\mathrm{ATP}}$ channel ( $\mathrm{Lu}$ et al. 2001). In pancreatic islets, $\mathrm{K}_{\mathrm{ATP}}$ channels are primarily composed of four pore-forming potassium subunits (Kir6.2) and four sulfonylurea receptor regulatory subunits (SUR1). Accumulative data suggests that $\mathrm{K}_{\text {ATP }}$ channels have a role in exocytosis (Ashcroft and Rorsman 2013). SUR1 binds to the exocytosis-regulating protein EPAC2 (exchange protein directly activated by cAMP 2) and other exocytotic proteins, such as syntaxin- $1 \mathrm{~A}$, and the $\mathrm{Ca}^{2+}$ sensor piccolo involved in exocytosis (Kang et al. 2011; Shibasaki et al. 2004).

Decreased expression of CYP2J2gene was also reported by Kim et al. (Kim et al. 2010) and Vanella et al. (Vanella et al. 2010). In such studies, the expression of CYP2J2 and EET level in hMSC-derived adipocytes were significantly lower than the undifferentiated cells.

It is worth noting that our finding of decreased 14, 15 EET that is associated with low insulin secretion from differentiated IPC contradicts with the previous study (Falck et al. 1983) that associates 14, 15 EET to glucagon rather than insulin secretion. The difference in that study is probably due to the use of rat islets that contains glucagon-secreting cells, in contrast to differentiated IPCs in our study. A limitation of this study is the small sample size used in correlation expermints. Further studies with larger sample size are neded to validate the results.

\section{Conclusions}

Our findings suggest that CYP2J2-derived 14, 15 EET could affect insulin and C-peptide secretion from HBM-MSC-derived IPCs. Further studies are required to verify whether interventions to increase 14,15 EET by EET agonists and sEH inhibitors could potentiate insulin secretion from MSC-derived IPCs.

\section{Abbreviations \\ 14, 15-DHET: 14, 15-Dihydroxyeicosatrienoic acid; BM-MSCs: Bone marrow- derived MSCs; CYP2J2: Cytochrome P4502J2; EETs: Epoxyeicosatrienoic acids; GSIS: Glucose-stimulated insulin secretion; hMSCs: Human mesenchymal stem cells; IPCs: Insulin-producing cells; PCR: Polymerase chain reaction; PDX- 1: Pancreatic duodenal homeobox-1}

\section{Acknowledgements}

The authors acknowledged the members of oncology diagnostic unit and Center of Excellence Laboratory, Faculty of Medicine, Suez Canal University. 


\section{Availability of data and materials}

All relevant data are included within the paper. Raw data are available from the corresponding author for researchers who meet the criteria for access to confidential data.

\section{Authors' contributions}

The authors contributed equally in this research. All authors read and approved the final manuscript.

\section{Ethics approval and consent to participate}

The study was approved by the faculty of medicine ethical committee, Suez Canal University.

A written informed consent was obtained from the participants.

\section{Consent for publication}

Not applicable

\section{Competing interests}

The authors declare that they have no competing interests.

\section{Publisher's Note}

Springer Nature remains neutral with regard to jurisdictional claims in published maps and institutional affiliations.

Received: 7 June 2018 Accepted: 5 October 2018 Published online: 22 October 2018

\section{References}

Abraham NG, Sodhi K, Silvis AM, Vanella L, Favero G, Rezzani R, Schwartzman ML et al (2014) CYP2J2 targeting to endothelial cells attenuates adiposity and vascular dysfunction in mice fed a high-fat diet by reprogramming adipocyte phenotype. Hypertension 64(6):1352-1361

Ashcroft FM, Rorsman P (2013) K (ATP) channels and islet hormone secretion: new insights and controversies. Nat Rev Endocrinol 9:660-669

Campbell WB, Fleming I (2010) Epoxyeicosatrienoic acids and endotheliumdependent responses. Pflugers Archiv 459(6):881-895

Chen L, Fan C, Zhang Y, Bakri M, Dong H, Morisseau C et al (2013) Beneficial effects of inhibition of soluble epoxide hydrolase on glucose homeostasis and islet damage in a streptozotocin-induced diabetic mouse model. Prostaglandins Other Lipid Mediat 104-105:42-48

Chen, L.B Jiang, X.B Yang, L. Differentiation of rat marrow mesenchymal stem cells into pancreatic islet beta-cells. World J Gastroenterol 2004; 10(20):3016-3020

Dominici M, le Blanc K, Mueller I, Slaper-Cortenbach I, Marini F, Krause D, Deans R, Keating A, Prockop DJ, Horwitz E (2006) Minimal criteria for defining multipotent mesenchymal stromal cells. The International Society for Cellular Therapy position statement. Cytotherapy 8(4):315-317

Falck JR, Manna S, Moltz J, Chacos N, Capdevila J (1983) Epoxyeicosatrienoic acids stimulate glucagon and insulin release from isolated rat pancreatic islets. Biochem Biophys Res Commun 114:743-749

Fina L, Molgaard HV, Robertson D, Bradley NJ, Monaghan P, Delia D et al (1990) Expression of the CD34 gene in vascular endothelial cells. Blood 75:2417-2426

Friedenstein AJ, Gorskaja JF, Kulagina NN (1976) Fibroblast precursors in normal and irradiated mouse hematopoietic organs. Exp Hematol 4:267-274

Gabr MM, Zakaria MM, Refaie AF, Ismail AM, Ashamallah SA, Khater SM, ElHalawani SM, Ghoneim MA et al (2013) Insulin-producing cells from adult human bone marrow mesenchymal stem cells control streptozotocininduced diabetes in nude mice. Cell Transplant 22(1):133-145

Gabr MM, Zakaria MM, Refaie AF, Khater SM, Ashamallah SA, Ismail AM, elHalawani SM, Ghoneim MA (2015) Differentiation of human bone marrowderived mesenchymal stem cells into insulin-producing cells: evidence for further maturation in vivo. Biomed Res Int 2015:e575837

Gang YU, Xiying WU, Dietrich MA, Polk PL, Scott K, Ptitsyn AA, Gimble JM (2010) Yield and characterization of subcutaneous human adipose-derived stem cells by flow cytometric and adipogenic mRNA analyses. Cytotherapy 12:538-546

Gangadhariah MH, Dieckmann BW, Lantier L, Kang L, Wasserman DH, Caskey CF et al (2017) Cytochrome P450 epoxygenase-derived epoxyeicosatrienoic acids contribute to insulin sensitivity in mice and in humans. Diabetologia 60:1066-1107
Hansson M, Tonning A, Frandsen U, Petri A, Rajagopal J, Englund MC, Heller RS, Håkansson J, Fleckner J, Sköld HN, Melton D, Semb H, Serup P (2004) Artifactual insulin release from differentiated embryonic stem cells. Diabetes 53(10):2603-2609

Hass R, Kasper C, Bohm S, Jacobs R (2011) Different populations and sources of human mesenchymal stem cells (MSC): a comparison of adult and neonatal tissue-derived MSC. Cell Commun Signal 9:12

Jafarian A, Taghikani M, Abroun S, Allahverdi A, Lamei M, Lakpour N, Soleimani M (2015) The generation of insulin-producing cells from human mesenchymal stem cells by MiR-375 and anti-MiR-9. PLoS One 10(6):e0128650

Kang Y, Zhang Y, Liang T, Leung YM, Ng B, Xie H, Gaisano HY (2011) ATP modulates interaction of syntaxin-1A with sulfonylurea receptor 1 to regulate pancreatic $\beta$-cell $K_{\text {ATP }}$ channels. J Biol Chem 286(7):5876-5883

Karara A, Dishman E, Falck JR, Capdevila JH (1991) Endogenous epoxyeicosatrienoyl-phospholipids. A novel class of cellular glycerolipids containing epoxidized arachidonate moieties. J Biol Chem 266:7561-7569

Karnieli O, Izhar-Prato Y, Bulvik S, Efrat S (2007) Generation of insulin-producing cells from human bone marrow mesenchymal stem cells by genetic manipulation. Stem Cells 25:2837-2844S

Kim DH, Vanella L, Inoue K, Burgess A, Gotlinger K, Manthati VL, Koduru SR et al (2010) Epoxyeicosatrienoic acid agonist regulates human mesenchymal stem cell-derived adipocytes through activation of HO-1-pAKT signaling and a decrease in PPARg. Stem Cells Dev 19:12

Kim HS, Hwang YC, Koo SH, Park KS, Lee MS, Kim KW, Lee MK (2013) PPAR-Y activation increases insulin secretion through the up-regulation of the free fatty acid receptor GPR40 in pancreatic $\beta$-cells. PLoS One 8(1):e50128

Klett EL, Chen S, Edin ML, Li LO, Ilkayeva O, Zeldin DC, Newgard CB, Coleman RA (2013a) Diminished acyl-CoA synthetase isoform 4 activity in INS 832/13 cells reduces cellular epoxyeicosatrienoic acid levels and results in impaired glucose-stimulated insulin secretion. J Biol Chem 288:21618-21629

Klett EL, Chen S, Edin ML et al (2013b) Diminished acyl-CoA synthetase isoform 4 activity in INS 832/13 cells reduces cellular epoxyeicosatrienoic acid levels and results in impaired glucose-stimulated insulin secretion. J Biol Chem 288(30):21618-21629

Lin G, Xin Z, Zhang H, Banie L, Wang G, Qiu X et al (2012) Identification of active and quiescent adipose vascular stromal cells. Cytotherapy 14:240-246

Livak KJ, Schmittgen TD (2001) Analysis of relative gene expression data using real-time quantitative PCR and the $2^{-\Delta \Delta C}$ T method. Methods 25(4):402-408

Lu T, Hoshi T, Weintraub NL, Spector AA, Lee HC (2001) Activation of ATPsensitive $\mathrm{K}^{+}$channels by epoxyeicosatrienoic acids in rat cardiac ventricular myocytes. J Physiol 537(3):811-827

Luo P, Chang HH, Zhou Y, Zhang S, Hwang SH, Morisseau C, Wang MH (2010) Inhibition or deletion of soluble epoxide hydrolase prevents hyperglycemia, promotes insulin secretion, and reduces islet apoptosis. J Pharmacol Exp Ther 334(2):430-438

Luo P, Wang MH (2011) Eicosanoids, $\beta$-cell function, and diabetes. Prostaglandins Other Lipid Mediat 95:1-4

Maleki M, Ghanbarv F, Behvarz MR, Ejtemaei M, Ghadirkhomi E (2014) Comparison of mesenchymal stem cell markers in multiple human adult stem cells. Int J Stem Cells 7:118-126

Mc Kiernan E, Barron NW, O'Sullivan F, Barham P, Clynes M, O'Driscoll L (2007) Detecting de novo insulin synthesis in embryonic stem cell-derived populations. Exp Cell Res 313(7):1405-1414

Moriscot C, De Fraipont F, Richard M, Marchand M, Savatier P, Bosco D, Favrot M, Benhamou P (2005) Human bone marrow mesenchymal stem cells can express insulin and key transcription factors of the endocrine pancreas developmental pathway upon genetic and/or microenvironmental manipulation in vitro. Stem Cells 23(4):594-603

Mouiseddine M, Mathieu N, Stefani J, Demarquay C, Bertho JM (2008) Characterization and histological localization of multipotent mesenchymal stromal cells in the human postnatal thymus. Stem Cells Dev 17:1165-1174

Node K, Huo Y, Ruan X, Yang B, Spiecker M, Ley K, Zeldin DC, Liao JK (1999) Antiinflammatory properties of cytochrome P450 epoxygenase-derived eicosanoids. Science 285:1276-1279

Rajagopal J, Anderson WJ, Kume S, Martinez OI, Melton DA (2003) Insulin staining of ES cell progeny from insulin uptake. Science 299(5605):363

Shibasaki T, Sunaga Y, Fujimoto K, Kashima Y, SEINO S (2004) Interaction of ATP sensor, CAMP sensor, Ca2+ sensor, and voltage-dependent $\mathrm{Ca} 2+$ channel in insulin granule exocytosis. J Biol Chem 279:7956-7961 
Simmons PJ, Torok-Storb B (1991) Identification of stromal cell precursors in human bone marrow by a novel monoclonal antibody, STRO-1. Blood 78:55-62

Sodhi K, Inoue K, Gotlinger KH, Canestraro M, Vanella L, Kim DH, Manthati VL et al (2009) Epoxyeicosatrienoic acid agonist rescues the metabolic syndrome phenotype of HO-2-nullmice. J Pharmacol Exp Ther 331:906-916

Stolzing A, Bauer E, Scutt AM (2012) Suspension cultures of bone marrow derived mesenchymal stem cells: effects of donor age and glucose level. Stem Cells Dev 21(14):2718-2723

Suga H, Shigeura T, Matsumoto D, Inoue K, Kato H, Aoi N et al (2007) Rapid expansion of human adipose-derived stromal cells preserving multipotency. Cytotherapy 9:738-745

Sun Y, Chen L, Hou XG, Hou WK, Dong JJ, Sun L et al (2007) Differentiation of bone marrow-derived mesenchymal stem cells from diabetic patients into insulin-producing cells in vitro. Chin Med J 120(9):771-776

Vanella L, Kim DH, Asprinio D, Peterson SJ, Barbagallo I, Vanella A, Abraham NG (2010) HO-1 expression increases mesenchymal stem cell-derived osteoblast but decreases adipocyte lineage. Bone 46(1):236

Vanella L, Kim DH, Sodhi K, Barbagallo I, Burgess AP, Falck JR, Abraham NG (2011) Crosstalk between EET and HO-1 downregulates Bach1 and adipogenic marker expression in mesenchymal stem cell derived adipocytes. Prostaglandins Other Lipid Mediat 96:54-62

Volarevic V, Al-Qahtani A, Arsenijevic N, Pajovic S, Lukic ML (2010) Interleukin1receptor antagonist (IL-1Ra) and IL-1Ra producing mesenchymal stem cells as modulators of diabetogenesis. Autoimmunity 43:255-263

Wang Y, Wei X, Xiao X, Hui R, Card JW, Carey MA, Wang DW, Zeldin DC (2005) Arachidonic acid epoxygenase metabolites stimulate endothelial cell growth and angiogenesis via mitogen-activated protein kinase and phosphatidylinositol 3-kinase/Akt signaling pathways. J Pharmacol Exp Ther 314:522-532

Watt SM, Karhi K, Gatter K, Furley AJ, Katz FE, Healy LE et al (1987) Distribution and epitope analysis of the cell membrane glycoprotein (HPCA-1) associated with human hemopoietic progenitor cells. Leukemia 1:417-426

Wray J, Bailey DB (2007) Epoxygenases and peroxisome proliferator-activated receptors in mammalian vascular biology. Exp Physiol 93(1):148-154

Xie H, Wang Y, Zhang H, Qi H, Zhou H, Li FR (2013) Role of injured pancreatic extract promotes bone marrow-derived mesenchymal stem cells efficiently differentiate into insulin-producing cells. PLoS One 8(9):e76056

Xie QP, Huang H, Xu B, Dong X, Gao SL, Zhang B, Wu YL (2009) Human bone marrow mesenchymal stem cells differentiate into insulin-producing cells upon micro-environmental manipulation in vitro. Differentiation 77:483-491

Xin $Y$, Jiang $X$, Wang $Y$, Su $X$, Sun $M$, Zhang $L$ et al (2016) Insulin-producing cells differentiated from human bone marrow mesenchymal stem cells in vitro amel iorate streptozotocin-induced diabetic hyperglycemia. PLoS ONE 11(1): e0145838

Xu M, Ju W, Hao H, Wang G, Li P (2013) Cytochrome P450 2J2: distribution, function, regulation, genetic polymorphisms and clinical significance. Drug Metab Rev 45(3):311-352

Zanini C, Bruno S, Mandili G, Baci D, Cerutti F, Cenacchi G, Izzi L, Camussi G, Forn M (2011) Differentiation of mesenchymal stem cells derived from pancreatic islets and bone marrow into islet-like cell phenotype. PLoS One 6(12):e28175

Zeldin DC, Foley J, Boyle JE, Moomaw CR, Tomer KB, Parker C, Steenbergen C, Wu S (1997) Predominant expression of an arachidonate epoxygenase in islets of Langerhans cells in human and rat pancreas. Endocrinology 138 1338-1346

\section{Submit your manuscript to a SpringerOpen ${ }^{\odot}$ journal and benefit from:}

- Convenient online submission

- Rigorous peer review

- Open access: articles freely available online

- High visibility within the field

- Retaining the copyright to your article

Submit your next manuscript at $\boldsymbol{\nabla}$ springeropen.com 